\section{Comparison of antiemetic efficacy of domperidone, metoclopramide, and dexamethasone in patients receiving outpatient chemotherapy regimens}

Nausea and vomiting during treatment with cytotoxic drugs lead to appreciable morbidity and in one study were considered to be the worst symptoms of chemotherapy. ${ }^{.}$Several antiemetic regimens have been developed to combat this problem, but many are either not totally effective or associated with appreciable toxicity, such as drowsiness and dryness of the mouth. ${ }^{2-4}$.

Metoclopramide, dexamethasone, and domperidone are widely used in clinical practice, but so far there has been no randomised trial to investigate which is most effective.

\section{Patients, methods, and results}

Sixty consecutive patients ( 39 women, 21 men; mean age 59, range 21-87 years) receiving chemotherapy without cisplatin were entered in the trial. Five had received previous chemotherapy. Chemotherapy was divided into regimens of high emetogenic potential (those containing intravenous doxorubicin, epirubicin, or cyclophosphamide; 14 patients receiving these regimens in each antiemetic group) and low emetogenic potential. Patients were randomly assigned by a single blind technique to one of three antiemetics: domperidone, metoclopramide, or dexamethasone (20 patients in each group). Domperidone $20 \mathrm{mg}$ thrice daily and metoclopramide $20 \mathrm{mg}$ thrice daily were given orally on the day before chemotherapy and continued for three days, with $20 \mathrm{mg}$ twice daily on day 4 after chemotherapy and $20 \mathrm{mg}$ on day 5 . Dexamethasone was given orally $4 \mathrm{mg}$ thrice

Control of emesis and side effects in all patients. Figures are numbers (\%) of patients

\begin{tabular}{|c|c|c|c|c|}
\hline Grade & $\begin{array}{l}\text { Severity of } \\
\text { symptom }\end{array}$ & $\begin{array}{c}\text { Domperidone } \\
(n=23)\end{array}$ & $\begin{array}{c}\text { Dexamethasone } \\
(\mathrm{n}=28)\end{array}$ & $\begin{array}{l}\text { Metoclopramide } \\
(\mathrm{n}=23)\end{array}$ \\
\hline $\begin{array}{l}0 \\
1 \\
2 \\
3 \\
4 \\
5\end{array}$ & $\begin{array}{l}\text { None } \\
1 \text { Episode } \\
2 \\
3 \\
4-6 \\
\geqslant 7\end{array}$ & $\begin{array}{l}\text { Vomiting } \\
13 \text { (56) } \\
1 \\
3 \\
5 \\
1\end{array}$ & $\begin{array}{l}21(75) \\
2 \\
5 \\
1\end{array}$ & $\begin{array}{l}6(26) \\
1 \\
8 \\
3 \\
4 \\
1\end{array}$ \\
\hline $\begin{array}{l}0 \\
1 \\
2 \\
3 \\
4\end{array}$ & $\begin{array}{l}\text { None } \\
1 \text { Episode } \\
2 \\
3 \\
46\end{array}$ & $\begin{array}{l}\text { Retching } \\
15(65) \\
1 \\
2 \\
4 \\
1\end{array}$ & $\begin{array}{l}22(79) \\
2 \\
2 \\
2\end{array}$ & $\begin{array}{l}12(52) \\
2 \\
4 \\
5\end{array}$ \\
\hline $\begin{array}{l}0 \\
1 \\
2 \\
3\end{array}$ & $\begin{array}{l}\text { None } \\
\text { Mild } \\
\text { Moderate } \\
\text { Severe }\end{array}$ & $\begin{array}{l}\text { Nausea } \\
8(35) \\
6 \\
3 \\
6\end{array}$ & $\begin{array}{c}16(57) \\
3 \\
3 \\
7\end{array}$ & $\begin{array}{l}5(22) \\
2 \\
7 \\
9\end{array}$ \\
\hline $\begin{array}{l}0 \\
1 \\
2 \\
3\end{array}$ & $\begin{array}{l}\text { Increased } \\
\text { Normal } \\
\text { Some solids } \\
\text { Liquids only }\end{array}$ & $\begin{array}{l}\text { Appetite } \\
1 \\
9 \\
5 \\
8\end{array}$ & $\begin{array}{r}1 \\
12 \\
8 \\
7\end{array}$ & $\begin{array}{r}8 \\
5 \\
10\end{array}$ \\
\hline $\begin{array}{l}0 \\
1\end{array}$ & $\begin{array}{l}\text { Normal } \\
\text { Symptoms but able to }\end{array}$ & $\begin{array}{l}\text { General activity } \\
9\end{array}$ & 11 & 7 \\
\hline $\begin{array}{l}2 \\
3\end{array}$ & $\begin{array}{l}\text { carry out normal duties } \\
\text { Symptoms and unable to } \\
\text { carry out normal duties } \\
\text { Bedridden }\end{array}$ & $\begin{array}{l}5 \\
1 \\
8\end{array}$ & $\begin{array}{l}5 \\
6 \\
6\end{array}$ & $\begin{array}{r}1 \\
4 \\
11\end{array}$ \\
\hline $\begin{array}{l}0 \\
1 \\
2 \\
3\end{array}$ & $\begin{array}{l}\text { None } \\
\text { Mild } \\
\text { Muderate } \\
\text { Severe }\end{array}$ & $\begin{array}{l}\text { Dyspepsia } \\
14(61) \\
5 \\
1 \\
3\end{array}$ & $\begin{array}{c}15(54) \\
8 \\
5\end{array}$ & $\begin{array}{l}11(48) \\
7 \\
3 \\
2\end{array}$ \\
\hline
\end{tabular}

daily on the day before chemotherapy and continued for three days, with $4 \mathrm{mg}$ twice daily on day 4 and $4 \mathrm{mg}$ on day 5 . On the day of chemotherapy the second dose of metoclopramide or dexamethasone was given as an intravenous bolus; domperidone was not available for intravenous administration. If the first antiemetic regimen failed to control nausea and vomiting patients were randomly allocated to one of the other regimens for their next course of chemotherapy, and if that failed they were allocated to the remaining regimen. Nausea, vomiting, retching, dyspepsia, appetite, and general activity were assessed on an inpatient basis for 24 hours after chemotherapy; and the patients completed a daily diary of these symptoms (graded as in the table) for at least the next five days or until the symptoms resolved. The scores for each antiemetic were compared with the Mann-Whitney test.

Nausea and vomiting were controlled in 12 of the patients given dexamethasone, five of those given metoclopramide $(p=0.005)$, and eight of those given domperidone (no significant difference from the other groups).

Of the 35 patients in whom first line treatment failed, 12 received a second option. Of these, six received dexamethasone and only one experienced nausea and vomiting; three received domperidone and three metoclopramide and all experienced nausea and vomiting. Of two patients given dexamethasone as third line treatment, one experienced nausea and vomiting. No patient was given metoclopramide or domperidone as a third line antiemetic. The table summarises the results for all courses of treatment. The median duration (range) in days of the symptoms were: nausea 3.5 (1-14); vomiting 2(1-13); retching 2(1-14); and time for appetite and general activity to return to normal $3(2-10)$ and $3 \cdot 5(2-14)$, respectively.

\section{Comment}

Monitoring the adverse effects of outpatient chemotherapy with a diary yielded important information about the duration of nausea and vomiting after chemotherapy. When nausea or vomiting occurs it may persist for several days, and occasionally for as long as two weeks, which reinforces the need to establish effective antiemetic treatment for patients who are receiving outpatient chemotherapy.

Dexamethasone was a significantly better antiemetic than metoclopramide and was also effective in patients in whom first line treatment with domperidone had failed. Dexamethasone compares favourably with other antiemetic regimens. ${ }^{2-4}$ It has few side effects, and we were surprised that dyspepsia was no more common with it than with metoclopramide and domperidone. It has no sedative effect and therefore could be easily combined with other antiemetics.

In conclusion, we found dexamethasone and domperidone to be effective antiemetics. Metoclopramide given at a dose of $20 \mathrm{mg}$ thrice daily was not successful, and its use cannot be recommended for clinical practice.

1 Coates A, Abraham S, Kaye SB, et al. On the receiving end-patient perception of the side-effects of cancer chemotherapy. Eur f Cancer Clin Oncol 1983;19:203-8.

2 Cunningham D, Soukop M, Gilchrist NL, et al. Randomised trial of intravenous high dose metoclopramide and intramuscular chlorpromazine in controlling nausea and vomiting induced by cytotoxic drugs. Br Med f 1985;290:604-5.

3 Cunningham D, Forrest GJ, Soukop M, Gilchrist NL, Calder IT, McArdle CS. Nabilone and prochlorperazine: a useful combination for emesis induced by cytotoxic drugs. $\mathrm{Br} \mathrm{Med} \mathcal{J}$ 1985;291:864-5.

4 Bakowski MT. Advances in anti-emetic therapy. Cancer Treat Rev 1984;11:237-56.

(Accepted 15 May 1987)

St George's Hospital, London SW17 0QT

DAVID CUNNINGHAM, MB, MRCP, senior registrar, medical oncology unit

CHRIS EVANS, BSC, MPS, staff pharmacist, medical oncology unit

JEAN-CLAUDE GAZET, MS, FRCS, consultant surgeon

HUBERT FORD, FRCR, consultant radiotherapist

ANDREA POPLE, SRN, research sister, medical oncology unit and Ludwig Institute for Cancer Research

JANE DEARLING, SRN, sister, day unit, medical oncology unit

DAVID CHAPPELL, MA, MB, senior house officer, medical oncology unit and Ludwig Institute for Cancer Research

CHARLES COOMBES, MD, PHD, consultant, medical oncology unit and Ludwig Institute for Cancer Research

Correspondence to: Dr Cunningham. 